\title{
Studia
}

\author{
Marcin Gajek \\ Collegium Civitas
}

\section{Ideologia i praktyka polityczna Solidarności a tradycja republikańska}

\author{
The ideology and political practise of Solidarity and republican tradition
}

\begin{abstract}
The paper argues that - regardless of neo-Marxist inspirations - many views of Václav Havel, Adam Michnik, or Jacek Kuroń on civil society bear a surprising resemblance to political philosophy of Aristotle or Cicero. This, in turn, makes it possible to argue that Havel's concept of "anti-political politics" is not anti-political at all but to the contrary - political par excellence, if only one adopts a sourcing understanding of politics characteristic for classical republican tradition. Moreover, those republican traces are especially well-visible in both the structure and the way of operating of Polish Solidarity movement.
\end{abstract}

Keywords - anti-political politics, republicanism, Solidarity

Lata siedemdziesiąte i osiemdziesiąte XX wieku odznaczały się wzrostem zainteresowania pojęciem społeczeństwa obywatelskiego wśród intelektualistów Europy Środkowo-Wschodniej. W czasie gdy koncepcja civil society na zachodzie kontynentu wydawało się już mało atrakcyjna, pojęcie to odżyło w krajach bloku komunistycznego dzięki nowym interpretacjom, jakim poddali je przedstawiciele demokratycznej opozycji. Rozwijane przez nich teorie przyczyniły się do swoistego renesansu owego pojęcia również wśród myślicieli zachodnich.

W literaturze przedmiotu podkreśla się zwykle silne inspiracje myślą Antonio Gramsciego, która odcisnęła piętno na sposobie myślenia wschodnio-europejskich dysydentów. W koncepcjach „nowego ewolucjonizmu” autorstwa Adama Michnika, czy ,anty-politycznej polityki” Václava Havla dopatrywano się - nie bez racji - śladów teorii włoskiego neo-marksisty ${ }^{1}$. Po bliższym przyjrzeniu się pismom wspomnianych opozycjonistów oraz praktyce działania ugrupowań opozycyjnych - szczególnie zaś polskiej Solidarności - można jednak dojść do wniosku, że rozwijane przez nich, a następnie wprowadzane w życie koncepcje miały równie wiele wspólnego z rozważaniami Gramsciego na temat hegemonii i „alternatywnego” społeczeństwa obywatelskiego, co z klasycznie republikańską koncepcja polityki. Celem niniejszego tekstu jest zinterpretowanie teorii społeczeństwa obywatelskiego, rozwijanych przez wybranych wschodnio-europejskich dysydentów, oraz ruchu społecznego, jakim była Solidarność, właśnie pod kątem tradycji republikańskiej. W efekcie takiej re-interpretacji okazać się może, że sposób rozumienia spraw publicznych zaproponowany przez wspomnianych wyżej dysydentów nie jest anty-polityczny, lecz polityczny par excellence - jeżeli tylko przyjąć źródłowe rozumienie polityki rozwijane przez klasycznych filozofów polityki takich jak Arystoteles, czy Cyceron.

${ }^{1}$ Zob. np. Z. Pełczyński, Solidarity and „The Rebirth of Civil Society” in Poland [w:] Civil Society and the State, red. J. Keane, London 1988, s. 365-369. 
Rzecz jasna, praktyka oraz formy działania Solidarności nie były dosłowną implementacją teoretycznych koncepcji rozwijanych w latach siedemdziesiątych XX wieku przez Kuronia, czy Michnika. Wiele z nich wykształciło się w sposób spontaniczny, a większość robotników podejmujących strajk w stoczni im. Lenina zapewne nie znała pism obu wspomnianych dysydentów. Niemniej jednak, działacze KOR i tzw. eksperci, zaproszeni przez robotników do rozmów z władzami, niewątpliwie wywarli pewien wpływ na strukturę oraz praktykę działania Solidarności², co zdaje się usprawiedliwiać powiązanie ze sobą w jednym tekście zarówno sposobu funkcjonowania Związku, jak i rozwijanych w latach siedemdziesiątych teorii społeczeństwa obywatelskiego.

\section{„Anty-polityczna polityka”, czyli o związkach polityki z etyką}

W jednym ze swoich najlepiej znanych esejów politycznych Václav Havel przedstawia się jako zwolennik „,polityki antypolitycznej” - to znaczy polityki rozumianej nie jako czysta technologia władzy i manipulacji, czy też cybernetyczna kontrola nad ludźmi, bądź sztuka tego, co użyteczne, ale „polityki jako jednego ze sposobów szukania i znajdowania sensu życia”. Pragnie on ,polityki jako moralności stosowanej w praktyce; jako służby prawdzie; jako najgłębszej ludzkiej (...) troski o bliźnich"3.

Jest rzeczą niezwykle znamienna, że tak rozumianą politykę przyszły prezydent Republiki Czeskiej określa mianem ,antypolitycznej” - sugerując tym samym, że pomiędzy sferą polityki (i to zarówno w jej komunistycznym, jak i zachodnio-kapitalistycznym wydaniu) i moralności istnieje zasadnicza sprzeczność. Tymczasem Havel w przywołanych wyżej słowach odnosi się do koncepcji, która w tradycji republikańskiej stanowi kwintesencję tego, czym jest i czym powinna być polityka. W tradycji tej, życie polityczne posiadało przede wszystkim wymiar etyczny, było wręcz praktyczną realizacją zaleceń etycznych. Nieprzypadkowo Etyka Nikomachejska była dla Arystotelesa swoistym wstępem do Polityki. Ostatecznym celem państwa było w jego przekonaniu „szczęśliwe życie”; wszystko inne to zaledwie „środki do tego celu wiodące”. Życie obywatelskie polegać miało również na zaprawianiu się w cnocie, państwo miało zaś swym obywatelom zagwarantować tę możliwość. Jego najwyższym, ostatecznym celem jest „możliwie doskonałe życie” 5 . Państwo jest więc w tradycji republikańskiej przestrzenią umożliwiająca samodoskonalenie; pełną realizację potencjału zawartego w ludzkiej naturze.

Rzecz jasna, Havel miał swoje powody aby przedstawiać etyczną wizję polityki jako antypolityczna. Czynił tak dlatego, że sfera polityki utożsamiana była przez niego z oficjalnym aparatem państwowym - realizującym marksistowską koncepcję polityki sprowadzonej do zarządzania; administrowania rzeczami i ludźmi. W koncepcji tej, co oczywiste, nie ma miejsca na moralność. Sprowadza ona politykę do wspomnianej przez Havla czystej „technologii władzy”. Przywrócenie polityce jej wymiaru etycznego miało mieć więc charakter aktu indywidualnego, dokonywanego przez jednostki niezależnie od władzy państwowej. Chodziło zatem, jak zauważa Jerzy Szacki „nie tyle o ucieczkę od polityki, ile o znalezienie takiego sposobu jej uprawiania, jaki byłby adekwatny do sytuacji społeczeństwa »posttotalitarnego« (...)"6.

Wydaje się, że w bardzo podobny sposób rozumowali również polscy opozycjoniści. Zdaniem Davida Osta, gdy KOR i Solidarność głosiły, że nie są ruchami politycznymi, dawały jedynie do zrozumienia, że nie zamierzaja bezpośrednio podważać partyjnej kontroli nad państwem. Polityka oznaczała dla nich domenę rządu oraz struktur administracyjnych i jako taka była przez opozycjonistów odrzucana. Nie oznaczało to jednak odrzucenia polityki rozumianej jako aktywność obywatelska 7 . Zdaniem Osta, w generalnym odrzuceniu władzy państwowej przez opozycję demokratyczną, a także w przekonaniu, że celem walki politycznej nie jest jedynie zmiana rządu, ale również

\footnotetext{
2 Zob. np. P. Gliński, The Self-governing Republic in the Third Republic, „Polish Sociological Review” 2006, nr 1 (153), s. 56.

${ }^{3}$ V. Havel, Polityka a sumienie, przeł. P. Godlewski [w:] idem, Siła bezsilnych i inne eseje, oprac. A. Jagodziński, Warszawa 2011, s. 188.

4 Arystoteles, Polityka, przeł. L. Piotrowicz, Warszawa 2004, 1281 a.

${ }^{5}$ Ibidem, 1328a.

${ }^{6}$ J. Szacki, Liberalizm po komunizmie, Kraków 1994, s. 97.

${ }^{7}$ D. Ost, Solidarity and the Politics of Anti-Politics. Opposition and Reform in Poland since 1968, Philadelphia 1990, s. 1-2. Por. V. Havel, Polityka..., s. 189.
} 
zmiana osobistego życia, tkwił swoisty pierwiastek anarchistyczny8. Ost zapomina jednak, że przekonanie jakoby działalność publiczna miała na celu współkształtowanie własnego charakteru i dążenie do etycznego samodoskonalenia, to wręcz kwintesencja Arystotelesowskiej - i republikańskiej w ogóle - wizji zrzeszenia politycznego.

Podobna intuicja pobrzmiewa w myśli Kuronia, gdy ten wskazuje, iż działalność opozycyjna znajdująca wyraz w sprzeciwie wobec destrukcji moralnej niesionej przez totalitaryzm jest zarazem działaniem wychowawczym. Praca nad ukształtowaniem w społeczeństwie ,postawy antytotalitarnej, wrażliwości moralnej, pluralizmu politycznego, tolerancji” jest jego zdaniem ściśle powiązana z wpajaniem ludziom „umiejętności politycznego myślenia i działania"9. I znowu, pomiędzy powyższym stwierdzeniem Kuronia a tradycją republikańską występują oczywiste punkty zbieżne. Rola obywatelskiej edukacji pełni w tej drugiej kluczową rolę. Zdaniem autora Politykki wychowanie obywatelskie jest wręcz podstawowym narzędziem umożliwiającym trwanie danego reżimu. „Najważniejszą (...) rzeczą dla zapewnienia trwałości ustrojów, ważniejszą od wszystkiego, co czym była dotąd mowa, choć dziś wszędzie zaniedbana, jest przystosowane do ustroju wychowanie. Na nic bowiem zdadzą się najzbawienniejsze prawa, wynikające ze zgodnej uchwały wszystkich obywateli, jeśli ludzie do nich nie przywykną i nie zostaną w duchu ustroju wychowani; a więc jeśli prawa są demokratyczne - w duchu demokratycznym, jeśli oligarchiczne - w duchu oligarchicznym" 10 .

Skoro rzeczpospolita opiera się na koncepcji dobra wspólnego, to zadaniem kluczowym w republice jest wpoić obywatelom gotowość działania na jego rzecz. Edukacja staje się narzędziem wychowawczym, dzięki któremu obywatele nabywają gotowość podporządkowania swoich indywidualnych interesów dobru publicznemu. Odgrywa więc ona istotną rolę w hierarchizacji ludzkich celów oraz pragnień. Doskonale współgra to z przytoczoną wcześniej myślą Kuronia, dla którego działalność edukacyjna ma na celu ukształtowanie obywateli „demokratycznych”; posługujących się w codziennym postępowaniu jasnymi kryteriami etycznymi; myślących oraz działających inaczej niż narzuca to logika systemu „posttotalitarnego”. Owa, prowadzona na co dzień, działalność wychowawcza byłaby więc całkowicie zgodna z założeniami „nowego ewolucjonizmu”: byłaby działalnością alternatywną wobec systemowego działania struktur państwowych - kształtujących model „,socjalistycznego człowieka”.

Nieodłącznym elementem owej alternatywnej edukacji obywatelskiej miało być przywrócenie pewnych elementarnych standardów etycznych i wpojenie wartości o charakterze moralnym. Dokładnie w ten sposób działalność opozycyjną rozumiał zapewne Havel, posługując się figurą kierownika sklepu warzywnego, który zaprzestaje rytualnego wywieszania czerwonych flag i powtarzania haseł wychwalających partię komunistyczną i Związek Radziecki. „Tym swoim buntem wydobędzie się z życia w kłamstwie; odrzuci rytuał i naruszy reguły gry; odnajdzie swoją zdeptaną tożsamość i godność; zrealizuje swą wolność. Jego bunt będzie próbą życia w prawdzie"11. Zarazem jednak, w systemie posttotalitarnym życie w prawdzie ma wymiar nie tylko egzystencjalny, czy moralny, ale również polityczny.

Nie ulega najmniejszej wątpliwości, że owa orientacja na swoistą odnowę moralną była również jedną z najbardziej charakterystycznych cech Solidarności. Zdaniem Timothy Garton Asha, dość powszechnie traktowana była ona przez jej członków jako instytucja powołana do wyrażenia protestu moralnego. Andrzej Gwiazda, w liście otwartym do Lecha Wałęsy, charakteryzował ją wręcz jako „ruch rewolucji moralnej”12.

Jak zauważa Zbigniew Pełczyński, Solidarność nie była jedynie pragmatycznym ruchem socjo-politycznym, zorientowanym na osiagnięcie pewnego konkretnego celu, czy - w szerszym kontekście - na przekształcenie struktury instytucjonalnej komunistycznego państwa. Miała ona nade wszystko charakter moralnej krucjaty, a jej członkowie często postrzegali konflikt z władzami w kategoriach walki dobra ze złem ${ }^{13}$. Podstawowym celem owej rewolucji moralnej miało być przywrócenie godności obywatelom komunistycznego państwa. W uchwałach programowych Związku godność była - obok wolności - najczęściej wymienianym słowem przedstawianym jako

\footnotetext{
${ }^{8}$ D. Ost, Solidarity..., s. 2-3.

${ }^{9}$ J. Kuroń, Politycżna oposycja w Polsce [w:] idem, Polityka i odpowiedz̧alność, Lublin 1986, s. 114.

10 Arystoteles, Polityka, 1310a.

${ }^{11}$ V. Havel, Sita bezsilnych, [w:] idem, Eseje polityczne, Warszawa 1984, s. 49.

12 T.G. Ash, Polska Rewolucja. Solidarność, Londyn 1987, s. 182.

13 Z. Pełczyński, Solidarity..., s. 372.
} 
wartość rugowana przez system komunistyczny, a zarazem jako przedmiot pragnień i cel walki związkowców ${ }^{14}$.

Jest rzeczą znamienna, że w oficjalnych deklaracjach często spychała ona na plan dalszy czysto materialne i pracownicze postulaty. W jednym z „Biuletynów Informacyjnych” Solidarności Ziemi Puławskiej można było przeczytać: „Biednemu pozostaje tylko godność i honor i tych już ostatnich wartości winien on strzec ponad wszystko, żadna cena nie jest tutaj za wysoka"15. Z kolei w Uchwale programowej I Krajowego Zjazdu Delegatów NSZZ „Solidarnośc” czytamy między innymi, że „[u] podstaw działania stać musi poszanowanie człowieka. Państwo ma służyć człowiekowi, a nie panować nad nim; organizacja państwowa ma służyć społeczeństwu i nie może być utożsamiona z jedna partia polityczną. Państwo musi być rzeczywiście wspólnym dobrem całego narodu"16. To właśnie przekonanie prowadziło następnie delegatów do stwierdzenia, iż „Związek będzie walczył z zakłamaniem we wszystkich dziedzinach życia ponieważ społeczeństwo chce i ma prawo żyć w prawdzie"17.

Podkreślenia wymaga fakt, iż etyczny postulat ochrony godności i przywrócenia standardów prawdy miał głęboko rewolucyjne i w gruncie rzeczy polityczne konsekwencje. Dotyczył bowiem kwestii rozumienia sfery polityki i jej praktycznego uprawiania; sytuował się na swoistym meta-poziomie - wyznaczającym najbardziej fundamentalne zasady życia politycznego i społecznego. I znowu, wypada zauważyć, że ujęcie takie przypomina bardzo mocno podejście republikańskie - podkreślające konieczność oparcia wspólnoty politycznej na pewnych zasadach o charakterze etycznym.

Jak trafnie ują to Zbigniew Stawrowski neo-republikańska (a zarazem niezwykle wierna swemu antycznemu archetypowi) wizja Hannah Arendt należy do wizji etycznych. „Polityka to w gruncie rzeczy poli-etyka, to wizja społeczności etycznej, wewnątrz której pojawia się dopiero doświadczenie współodpowiedzialności i wspólnej debaty nad konkretną realizacją wspólnego dobra. Związek polityczny równych i wolnych jednostek (...) może funkcjonować jedynie na podstawie trwałych i niepodważalnych fundamentów etycznych (...). Bez wspólnego doświadczenia etycznego, bez zgody co do elementarnych wartości, debata równych i wolnych jednostek nigdy nie będzie przyjacielską rozmowa, a wypowiadane w niej słowa okażą się po prostu orężem w bezwzględnej walce o panowanie"18.

W powyższym kontekście doświadczenie pierwszej Solidarności jawi się nie tylko jako ruch „etycznego odrodzenia" domagający się przywrócenia i przestrzegania kryteriów moralnych w życiu prywatnym i publicznym, ale nade wszystko jako próba powtórzenia swoistego aktu założycielskiego prawdziwej wspólnoty obywatelskiej, której istnienie w warunkach totalitarnego zakłamania było po prostu niemożliwe. Słusznie zauważył więc Kowalski, że o ile większość definicji godności formułowanych przez filozofów przypisuje jej charakter indywidualny, o tyle „z punktu widzenia związkowców mogła być to cecha posiadana kolektywnie - przez naród, społeczeństwo, świat pracy lub związek"19. To zaś prowadzi nas do kolejnego punktu rozważań na temat zbieżności pomiędzy tradycja republikańską a ideologią i praktyką polskich ruchów opozycyjnych.

\section{Społeczeństwo obywatelskie czy republikańska wspólnota?}

Jak zaobserwował David Ost, sednem anty-politycznej polityki prowadzonej przez KOR, a następnie Solidarność było upodmiotowienie obywateli oraz wyrobienie w nich poczucia własnej wartości, a zarazem godności - jako ludzi i obywateli jednocześnie ${ }^{20}$. Warto jednak podkreślić, że tak rozumiana polityka jest całkowicie zbieżna z jej republikańskim rozumieniem, w którym to poczucie wartości człowieka - zwierzęcia politycznego (zoon politikon)

\footnotetext{
${ }^{14}$ S. Kowalski, Solidarność polska. Studium z socjologii myślenia potocznego, Warszawa 1988, s. 83.

${ }^{15}$ Cyt. za S. Kowalski, Solidarność..., s. 84.

16 Uchwata programowa I Krajowego Zjazdu Delegatón Niezalę̇nego Samorzadnego Zwiazku Zawodowego „Solidarnośc”, http://www.wszechnica.solidarnosc.org.pl/?page_id=1370 (dostęp: 6 kwietnia 2016 r.).

17 Ibidem.

18 Z. Stawrowski, Doświadczenie 'Solidarności' jako wspólnoty etycznej [w:] Lekcja Sierpnia. Driedzictwo „, Solidarności” po dwudziestu latach, red. D. Gawin, Warszawa 2002, s. 106-107.

${ }^{19}$ S. Kowalski, Solidarność..., s. 84.

${ }^{20}$ D. Ost, Solidarity..., s. 4.
} 
- wypływa właśnie z jego obywatelskiej podmiotowości. Republika to zrzeszenie polityczne ludzi wolnych i stanowiących realne źródło wszelkich politycznych decyzji. Ludzka godność w prezentowanym tu ujęciu wypływa bezpośrednio z ich statusu jako obywateli - a więc tych, z którymi władza musi się liczyć, którzy nie podlegają żadnej arbitralnej i niezależnej od siebie wyższej zwierzchności (charakteryzującej stosunki panujące w ustroju monarchicznym, ale też stosunki pomiędzy panem a niewolnikiem). Pomiędzy klasycznym republikanizmem, a teoriami społeczeństwa obywatelskiego jako sfery społecznej aktywności - niezależnej od komunistycznej władzy - nie zachodzi zatem żadna sprzeczność. Wręcz przeciwnie. Prawdziwa wolność (w znaczeniu jak najbardziej politycznym), jak przypomina Hannah Arendt, „sytuuje się w dziedzinie tego, co społeczne, a siła lub przemoc stają się monopolem rządu"21.

Podobny sposób rozumowania prezentował Kuroń, gdy sugerował, że w państwie totalitarnym każda aktywność społeczna wymykająca się spod kontroli państwa - czy będzie to działalność o charakterze sportowym, kulturalnym, czy też czysto towarzyskie dyskusje na temat przeczytanej książki - staje się de facto działalnością polityczną. To, co społeczne staje się więc polityczne ${ }^{22}$. Dochodzi tu zatem (nieco kuriozalnie - bo zapewne nie to było intencją Kuronia) do zniesienia nowożytnej, wprowadzonej przez liberalną filozofię polityczna, dychotomii pomiędzy sferą społeczną i polityczną dychotomii kompletnie nieznanej starożytnym, którzy całkowicie utożsamiali ze sobą obie sfery. W klasycznym republikanizmie, wszystko co odbywało się w sferze publicznej - w sferze wzajemnych interakcji pomiędzy obywatelami - miało swą polityczną doniosłość; wpływało na kształt oraz życie wspólnoty politycznej.

Myśl Kuronia - choć wynikająca z innych źródeł i intelektualnych inspiracji - pozostaje w zaskakującej zbieżności ze sposobem rozumowania starożytnych myślicieli republikańskich, dla których polis nie sprowadzało się do zbioru instytucji oraz urzędów ustanowionych na określonym terytorium, ale stanowiło emanację codziennych, powtarzalnych interakcji pomiędzy obywatelami. W powyższy kontekst znakomicie wpisuje się również przesłanie rozwijanej przez Michnika koncepcji „,nowego ewolucjonizmu”, zgodnie z którą: „Każdy akt oporu pozwala i umożliwi wybudowanie już dziś zrębów struktury socjalizmu demokratycznego, który winien być nie tylko i może nawet nie głównie - struktura prawną instytucjonalną, ale nade wszystko rzeczywistą, codziennie współtworzoną wspólnotą ludzi wolnych [wyróżnienie M.G]"23. Michnik, ze względu na osobiste inspiracje i poglądy, pisze o zbudowaniu „socjalizmu demokratycznego”, ale sposób w jaki go rozumie jest całkowicie zbieżny z ustrojem republikańskim: jego sens nie sprowadza się do „struktury prawno-instytucjonalnej”, ale do realnej tworzonej dzięki codziennym interakcjom - obywatelskiej wspólnoty.

Do podobnej konkluzji skłania lektura pism Havla, który w znanym eseju Siła bezsilnych stwierdza, iż działalność opozycyjna - rozumiana tutaj jako aktywność społeczna niezależna od kontroli państwa (zbieżność z koncepcja „,nowego ewolucjonizmu” Michnika wydaje się być poza dyskusja) - prowadzi do powstania „,równoległej polis”: „ukazuje perspektywę i ma sens jedynie jako akt pogłębienia odpowiedzialności wobec ogółu i za ogół (...), nie zaś jako uchylenie się od niej”24. A zatem ,anty-polityczna polityka” nie powinna być w żadnym wypadku rozumiana jako postawa swoistej wewnętrznej emigracji. Nie polega ona bynajmniej na ucieczce jednostki od zewnętrznego świata polityki - zdominowanego przez totalitarne stosunki pomiędzy władzą a społeczeństwem - i zamknięciu się w kręgu spraw prywatnych, pozwalających na zachowanie elementarnych standardów etycznych. Wręcz przeciwnie: „równoległa polis”, o której pisze Havel, to sfera uświadomionej współzależności od innych, a zarazem postawa współodpowiedzialności za wspólnotę jako całość.

Klasycznie republikańskie pojęcie dobra wspólnego aż ciśnie się w tym miejscu na usta. Samo pojęcie republiki jest wszak w sensie etymologicznym tożsame z dobrem wspólnym. Bodaj najdosadniej ujął to Cyceron pisząc, iż: „[r]zeczpospolita (...) to wspólna sprawa, o którą dbamy pospołu”25. Republikańska polis jest zatem sferą wzajemnej współodpowiedzialności; jej istota dalece wykracza poza czysto kontraktualistyczne relacje pomiędzy obywatelami.

${ }^{21}$ H. Arendt, Kondycja ludzka, Warszawa 2000, s. 37.

22 J. Kuroń, Polityczna opozycja..., s. 119-120. Por. D. Ost, Solidarity..., s. 66.

23 A. Michnik, Nowy ewolucjonizm, [w:] idem, Szanse polskiej demokracji, Londyn 1984, s. 87.

${ }^{24} \mathrm{~V}$. Havel, Siła bersilnych, s. 73.

${ }^{25}$ Cyceron, O państwie [w:] idem, O państwie. O prawach, Kęty 1999, s. 26. Nieco dalej dodaje zaś, że „państwo jest z definicji rzeczpospolita, o którą obywatele troszczą się pospołu”, ibidem, s. 27. 
Doskonale wpisują się w ten obraz rozważania Havla, który określił ruchy dysydenckie mianem wspólnot (wyraźnie odróżniając je od organizacji) żyjących „przede wszystkim dzięki wspólnemu poczuciu głębokiego sensu swej działalności”. Przepełnia je atmosfera, w której „,więzi sformalizowane i zrytualizowane zastępuje żywe poczucie solidarności i braterstwa" 26 . Nie byłoby wielką przesadą stwierdzić, że pod powyższymi słowami mogliby się zapewne podpisać wszyscy klasycy myśli republikańskiej, dla których republika oznaczała przede wszystkim dzielenie pewnego sposobu życia (uznanego za wartościowy i godny upowszechnienia), a zarazem gotowość do działania na rzecz dobra wspólnego (pojmowanego jako ważniejsze i mające priorytet nad jednostkowymi, egoistycznymi interesami).

Koncepcję dobra wspólnego oraz pojmowanie ruchów społecznych w kategoriach wspólnoty odnajdziemy również w sposobie myślenia, jakie zdominowało praktykę Solidarności. Sergiusz Kowalski w swoim „studium z socjologii myślenia potocznego", charakteryzując Solidarność stwierdza, iż przyjmowano jako rzecz oczywista, „że istnieje rzecz taka, jak wola zbiorowa, której każdorazowym celem i przesłanką jest zbiorowe dobro będące nie tyle rezultatem zsumowania lub uśrednienia poszczególnych interesów jednostkowych, co pewną preegzystującą i nadrzędną realnością. Przyjmuje się też, że w ramach prawidłowo funkcjonującej wspólnoty znika konieczność podporządkowania interesów jednostkowych interesowi zbiorowemu, jako że są one jego zawężająca konkretyzacją. Stosowny sposób postępowania może być jednoznacznie wywiedziony z ogólnych celów i zasad”27.

Analogie pomiędzy przytoczoną charakterystyką Solidarności, a klasycznym republikanizmem są wyraźne. Arystoteles nie pozostawiał watpliwości, co do tego, że choć państwo jest wspólnotą złożoną z wielu różnych części, to jednak ma ono pierwszeństwo w stosunku do jednostki (jako całość w stosunku do części). Logicznie wynika z tego, iż istnieje również pewien interes zbiorowy (dobro wspólne), które ma charakter pierwotny w stosunku do interesów jednostkowych, a zarazem nie da się sprowadzić do czysto arytmetycznej ich sumy, czy też wypadkowej - jak ma to miejsce w tradycji liberalnej, szczególnie w wydaniu utylitarystycznym prezentowanym np. przez Jeremy'ego Benthama ${ }^{28}$.

Niezwykle istotnym i wartym podkreślenia rysem Solidarności było przekonanie o realności wspólnoty tworzonej przez jej członków. Jak twierdzi Ryszard Legutko, nazwa ruchu trafiała w sedno owego doświadczenia wspólnoty; wyrastała „z przekonania, iż podziały klasowe, płciowe czy zawodowe w społeczeństwie są mniej ważne od poczucia duchowej wspólnoty, i że w sytuacji trudnej owo poczucie przemawia silniej niż wszelkie antagonizmy"29. To właśnie z owego poczucia jedności wyrasta republikańska koncepcja dobra wspólnego. Realia starożytnych polis - mimo istniejących w nich antagonizmów - to realia polityki przed-partyjnej. Podziały frakcyjne postrzegane były jako niebezpieczne i potencjalnie zagrażające istnieniu państwa.

Jak przypomina Paweł Śpiewak, zarówno Herodot, jak i Arystoteles zgodnie przyznawali, że demokracja „nie zna podziałów partyjnych i że demos jest politycznie zgodny”30. Ów republikański ideał „jedności ludu” przetrwa zresztą do czasów nowożytnych (choć towarzyszyć mu będzie coraz częściej pojawiające się przekonanie, iż jest ideałem niemożliwym do utrzymania). Jeszcze u schyłku XVIII wieku Jerzy Waszyngton, gdy opuszczał fotel prezydencki, przestrzegał w mowie pożegnalnej swych współobywateli przed podziałami frakcyjnymi jako zasadniczym niebezpieczeństwem dla dalszego trwania młodej republiki amerykańskiej31. Jeden z najlepiej znanych i najczęściej cytowanych esejów z serii Federalista, autorstwa Jamesa Madisona, choć wychodzi z realistycznego założenia o niemożności zapobieżenia powstawaniu fakcji, poświęcony jest w całości rozważaniom na temat zapobiegania ich zgubnym dla republikańskiego państwa efektom ${ }^{32}$.

${ }^{26}$ V. Havel, Siła bezsilnych, s. 81-82.

${ }^{27}$ S. Kowalski, Solidarność..., s. 164-165.

${ }^{28}$ Nie oznacza to jednak konieczności całkowitego poświęcenia szczęścia indywidualnego na rzecz wspólnoty politycznej. „[P]aństwo jako całość nie może być szczęśliwe, gdy szczęścia nie będą odczuwać wszystkie jego części”. Arystoteles, Polityka, $1264 \mathrm{~b}$.

${ }^{29}$ R. Legutko, Społeczeństwo otwarte a etos solidarności [w:] Wiara i wolność. Doświadczenie i dziedzictwo pierwsz̨ej „Solidarności”, red. ks. A. Kobyliński, Płock 2001, s. 125.

30 P. Śpiewak, Obietnice demokracji, Warszawa 2004, s. 70.

${ }^{31}$ G. Washington, Przemówienie pożegnalne do narodu Stanów Zjednoczonych [w:] Wiæje Stanów Zjednoczonych w pismach Ojców Zatożycieli, oprac. W. Osiatyński, Warszawa 1977, s. 150, 153, 154.

${ }^{32}$ Zob. J. Madison, Federalista nr 10 [w:] Eseje polityczne federalistów, red. F. Quinn, Kraków 1999. 
Warto w tym kontekście przypomnieć, że zwalczanie podziałów frakcyjnych było powszechnie przyjęta praktyką w Solidarności. Dbano bardzo mocno, aby wybory delegatów nie przeradzały się w walkę pomiędzy rywalizującymi stronnictwami. Wyznawano zasadę, iż głosuje się na konkretnego człowieka, a nie na ugrupowanie. Zdecydowanie potępiano wszelkiego rodzaju partykularyzmy - polityczne, regionalne, czy zakładowe ${ }^{33}$. Uchwała programowa I Krajowego Zjazdu Delegatów NSZZ „Solidarność” stwierdzała wyjątkowo jasno: „Jesteśmy (...) przeciwni temu by statutowe władze nasze Związku tworzyły organizacje o charakterze partii politycznych"34. Partykularyzacja i rozdrobnienie interesów wydawały się czymś szczególnie niebezpiecznym w kontekście walki z dużo silniejszym przeciwnikiem, jakim był - względnie monolityczny, a na pewno silnie zdyscyplinowany - komunistyczny aparat partyjny. W gazetce wydawanej przez pracowników pewnej elektrowni pisano: „Źródłem, siłą i racją istnienia 'Solidarności' jest jedność zrzeszonych w niej środowisk (...)”35. Działalność uczestników Związku nakierowana była więc na dobro wspólne. Niezgoda, spór były pojęciami odnoszącymi się do rzeczywistości znajdującej się „na zewnątrz" solidarnościowej wspólnoty. Pojawiały się one tam, gdzie następowała styczność z władzą i oficjalnymi strukturami państwa.

Trzeba podkreślić, iż wspomniana jedność nie dotyczyła jedynie robotników pracujących w różnych zakładach. Była to jedność ponad-środowiskowa: obejmująca tak robotników, jak chłopów, czy inteligencję. Jak przypomina Dariusz Karłowicz: „Sierpień pamiętamy jako urzeczywistnienie mitu politycznej agape, która połączyła ludzi wszystkich stanów i biografii. Potoczny wizerunek tamtych czasów nie nosi na sobie śladów pęknięć, różnic zdań i formacji, w które obfitowało życie codzienne ogromnego ruchu politycznego"36.

Związek Solidarność stanowił zatem swoistą emanację wspólnoty i jedności narodowej, a nie tylko klasy robotniczej. Owo poczucie było zresztą w dużym stopniu usprawiedliwione masowością Solidarności, która, w przeciagu niespełna pół roku od sierpniowych strajków liczyła już wiele milionów członków. Związek traktowano więc jako całość, a jednocześnie - jako reprezentację całego społeczeństwa. Jak tłumaczy Kowalski: „Im bardziej organiczny charakter przybierała wspólnota, tym wyraźniej okazywało się, że dobro, interes lub zdanie ogółu wyłaniają się nie drogą agregacji dóbr, interesów, lub zdań partykularnych, poprzez rywalizację i kompromis, ale drogą przekładania tego co ogólne na język sytuacyjnego konkretu; są więc znane a priori. Związkowcy z różnych regionów, środowisk zawodowych i innych grup społecznych tworzących wspólnotę, w różnym czasie i miejscu natrafiają na różne konkretne problemy, każdorazowo jednak ich dążenia winny być uszczegółowieniem uniwersalnych dążeń Związku jako całości" ${ }^{37}$.

Powyższy opis stoi w jaskrawej sprzeczności z pluralistyczną wizją relacji społecznych, w których wszelkie postanowienia są efektem wzajemnych przetargów i swoistej umowy. W przypadku Solidarności mieliśmy do czynienia nie z liberalnym, a z republikańskim właśnie rozumieniem wspólnoty, w której to poczucie jedności i pewnego wspólnego dobra przeważa nad jednostkowymi pragnieniami i interesami. Owa przewaga ma nie tyle charakter jakiegoś na poły magicznego pogodzenia interesów indywidualnych, co wynika z przesłanek emocjonalnych. Zasadza się na odczuwaniu przywiązania do wspólnoty (a co za tym idzie - gotowości do poświęcenia się na jej rzecz). Już Monteskiusz zauważył, że cnota republikańska, to nic innego jak „miłość rzeczypospolitej”38. Ma więc ona charakter na wskroś emocjonalny, nie wynika z chodnej kalkulacji. Owa miłość skłania ludzi do „wyrzeczenia się samego siebie”, do „przełożenia dobra publicznego nad własne”39.

\footnotetext{
${ }^{33}$ Zob. S. Kowalski, Solidarność..., s. 159.

34 Statut, Uchwała Programowa z aneksem, dokumenty I Zjazdu Solidarności (teza 19), http://www.wszechnica.solidarnosc.org.pl/?page_id=612 (dostęp: 6 kwietnia 2016 r.).

${ }^{35}$ Cyt. za S. Kowalski, Solidarność..., s. 138.

36 D. Karłowicz, „Solidarnośc” jako kościót [w:] Lekcja Sierpnia, s. 43. Również Lawrence Goodwyn zauważa, że „jako ruch skupiający większość dorosłej ludności kraju, Solidarność objęła w swoich strukturach liczne grupy społeczne i orientacje polityczne o potencjalnie sprzecznych interesach i celach". L. Goodwyn, Jak to zrobiliscie? Powstanie Solidarności w Polsce, Gdańsk 1992, s. 410.

${ }^{37}$ S. Kowalski, Solidarność, s. 137-138.

38 Monteskiusz, O duchu praw, Kraków 2003, s. 45. W innym miejscu powie on, iż cnota polityczna ,jest to miłość ojczyzny”, ibidem, s. 5.

${ }^{39}$ Ibidem, s. 39.
} 
Republikańska wspólnota opiera się zatem na silnej więzi emocjonalnej (dokładnie taki wymiar ma też Arystotelesowskie pojęcie „przyjaźni” - umożliwiającej trwanie państwa). Jak twierdzi Dariusz Gawin: „Węzeł jedności to nic innego jak bezpośrednio odczuta natura tego, co wspólne (...). Patos sierpniowych strajków wynikał z przemożnego wzruszenia, które ogarniało ludzi bezpośrednio uczestniczących w rozniecaniu zarówno wspólnej woli, jak i wspólnych uczuć. Wspólnota woli i uczuć pozwoliła zaś ustanowić wspólną dla wszystkich »sprawę« - »res publikę«, czyli Solidarność (...) W tym też sensie można interpretować Sierpień jako wielką republikańską rewolucję, której moralna siła płynęła z przywrócenia ludziom możliwości równego uczestnictwa w działaniu na rzecz wspólnego dobra"40.

Podobnie Stawrowski twierdzi, że najważniejsze w doświadczeniu Solidarności „było niezwykle intensywne doświadczenie wspólnoty. Najbardziej istotny sens pierwszej 'Solidarności’ to powszechna świadomość głębokiego związku z innymi ludźmi”"41. W owym poczuciu wspólnoty rolę pierwszoplanową odgrywała zatem więź o charakterze emocjonalnym. Solidarność nie znosiła przecież w magiczny sposób wszelkich różnic poglądów i interesów pomiędzy jej członkami. Budowała jednak poczucie wspólnoty, co w państwie o charakterze autorytarnym (czy semi-totalitarnym) miało niebagatelne znaczenie. Zdaniem Arendt, wszelki porządek totalitarny opiera się na maksymalnej izolacji i atomizacji społeczeństwa. Zanik poczucia wspólnoty pomiędzy poszczególnymi obywatelami stanowi warunek sine qua non istnienia i przetrwania totalitaryzmu. Solidarność wyrwała polskie społeczeństwo z owej izolacji, a tym samym walnie przyczyniła się do obalenia komunizmu. Warto też podkreślić, iż poczucie wspólnoty - w znaczeniu o jakim tu mówimy - miało swój bezpośredni wymiar polityczny. Solidarność jako ruch przywracający godność obywatelom żyjącym w realiach komunistycznego reżimu, przyczyniała się nie tylko do odrodzenia poczucie bliskości, ale też do powstania wspólnoty o charakterze politycznym - w klasycznym rozumieniu tego terminu „Zbiorowość taka - pisze Gawin - musiała się przekształcić w obywatelską wspólnotę. Sens etyczny Sierpnia przeistaczał się w jego sens polityczny - tak jak jednostki stawały się osobami, tak też tłum, »ludność« stawała się »ludem«"42.

\section{Samorządna Rzeczpospolita}

„Władze państwową w naszym kraju - pisał Kuroń w tekście zatytułowanym Notatki o samorzqdzie - sprawuje się w oparciu o wywłaszczenie społeczeństwa z inicjatywy, informacji, decyzji. Każda samorządna inicjatywa społeczna narusza monopol państwa i tym samym podstawy sprawowania władzy"43. Powyższy zarzut bez wątpienia odzwierciedlał poczucie powszechne wśród polskiej (i nie tylko) opozycji politycznej; poczucie swoistego ubezwłasnowolnienia obywateli i pozbawienia ich realnego wpływu na rzeczywistość społeczno-polityczną. Opozycjoniści domagali się możliwości wywierania realnego wpływu na władzę i możliwości samo-rządzenia, a jednocześnie podkreślali olbrzymią wagę obywatelskiej aktywności, bez której prawdziwy samorząd nie jest możliwy.

Realia systemu komunistycznego nie tylko sprzyjały bierności (i wspomnianej już izolacji jednostek). Komunistyczne władze były żywo zainteresowane utrzymaniem niskiego poziomu aktywności politycznej w społeczeństwie. To właśnie z tego powodu Bronisław Geremek zauważył, że wyjście z komunizmu wymaga ludzkiej aktywności, a nie bierności. „Samorząd jest, jak się zdaje, jedynym sposobem na pobudzenie postawy aktywnej” ${ }^{44}$. Tę samą myśl powtórzył nieco później Havel pisząc, iż „Jedynie pełna egzystencjalna odpowiedzialność każdego członka społeczeństwa mogłaby chyba stać się trwałą zaporą przeciw pełzającej totalizacji”. Podkreślał on również, że struktury samorządowe - aby spełniać powyższą rolę - powinny powstawać oddolnie, ,jako następstwa autentycznej samoorganizacji społecznej”. Chwilę później zaś dodawał: „Na różnorodnej i zmiennej współpracy takich właśnie organizmów, dynamicznie powstających i zanikających - przede wszystkim jednak żyjących dzięki swemu głębokiemu aktualnemu sensowi i spajanych więziami międzyludzkimi - powinno opierać się życie polityczne, a

\footnotetext{
40 D. Gawin, „Solidarnośc” - republikańska rewolucja Polaków, [w:] Lekcja Sierpnia, s. 170-171.

${ }^{41}$ Z. Stawrowski, Doświadczenie 'Solidarności'..., s. 104.

42 D. Gawin, „Solidarość”..., s. 168.

${ }^{43}$ J. Kuroń, Notatki o samorzadzie [w:] idem, Polityka i odpowiedzialność, s. 58.

${ }^{44}$ Cyt. za T.G. Ash, Polska rewolucja..., s. 122.
} 
także gospodarcze: jeżeli o nie chodzi, to wierzę w zasade samorzadności, która jedynie chyba może zapewnić to, o czym śnili teoretycy socjalizmu, mianowicie rzeczywisty /tzn. nieformalny/ udział ludzi pracy w podejmowaniu decyzji gospodarczych i poczucie rzeczywistej odpowiedzialności za rezultaty wspólnej pracy”45.

W powyższym cytacie Havel trafnie ujął istotę samorządu. Jest nią bowiem realny udział obywateli w procesie podejmowaniu decyzji dotyczących wszelkich spraw, które przekładają się na ich życie. Poważne zastrzeżenie budzić musi natomiast przekonanie czeskiego dysydenta jakoby zasadę tę „wyśnili teoretycy socjalizmu”. Bliższe prawdy byłoby stwierdzenie, iż zasadę tę opisali (oraz skutecznie praktykowali) klasyczni republikanie. Havel, któremu - podobnie jak Michnikowi, czy Kuroniowi - bliskie były ideały lewicy z pewnością czuł się lepiej w obrębie socjalistycznych teorii rozwijających modele rad robotniczych, co tłumaczy fakt powołania się przezeń na teoretyków socjalizmu.

Nie zmienia to jednak faktu, iż koncepcja samorządu stanowi trzon republikańskiego rozumienia polityki i wolności politycznej. Republikańska tradycja niezwykle mocno akcentuje rozróżnienie pomiędzy poddanym, a obywatelem. Tego drugiego charakteryzuje „prawo udziału w sądach i rządzie”. Obywatelami są ci, „którzy uczestniczą w rządzeniu państwem"46. Aktywny udział w życiu politycznym jest zatem cechą niejako definiującą obywatela. Niewątpliwie to tu właśnie tkwią korzenie - wyniesionej na piedestał przez XVIII-wiecznych demokratów zasady suwerenności ludu opartej na przekonaniu, iż każdy obywatel dysponuje taką samą częścią suwerennej władzy i na równi z innymi bierze udział w rządzeniu państwem. Wolność bowiem, jak zauważył Cyceron, „nie polega na tym, by służyć dobremu panu, lecz by nie mieć nad sobą żadnego" 47 .

Mimo odmiennych inspiracji intelektualnych oraz tradycji politycznych, poglądy wschodnio-europejskich dysydentów dotyczące roli oraz znaczenia samorządu są w pełni zbieżne z klasycznym republikanizmem. I tak na przykład Kuroń pisał, iż w określeniu „rządzić się samemu” chodzi o to, aby „nie oddzielać programowania i zarządzania od wykonawstwa" 48 . Pod powyższym stwierdzeniem z pewnością mógłby się podpisać Arystoteles, dla którego samorząd oznaczał realny udział w sprawowaniu władzy na każdym jej etapie - a zatem na etapie podejmowania uchwał przez Zgromadzenia Ludowe (Ekklesia) oraz na etapie ich wykonawstwa. Gdy w tym samym tekście Kuroń dodawał: „Spółdzielnie, stowarzyszenia, kluby sa zatem nie po to, aby ułatwić zaopatrzenie, zbudować mieszkanie, obronić zabytki i opiekować się dziećmi, ale także i po to, aby samorządzić, czyli suwerennie tworzyć swoje życie"49 - doskonale ukazywał (zapewne nieświadomie) republikańską wizję wolności politycznej polegająca na suwerennym decydowaniu o losie własnym oraz własnej wspólnoty politycznej. Republikańska wizja samorządu podkreślała jednak nie tylko wymiar stricte polityczny podejmowanych decyzji, ale również ich znaczenie z punktu widzenia życia poszczególnych jednostek. Być obywatelem polis znaczyło samodzielnie kształtować swoje życie i otaczająca je rzeczywistość społeczno-polityczna.

Dokładnie taki sam charakter, jak się wydaje, miały postulaty Solidarności. Jak zauważa Ost, nieschodzące w latach 1980-81 z ust związkowych działaczy słowo „podmiotowość” wskazywało jasno na konieczność aktywnego samodzielnego działania. Wyrażało przekonanie, że polityka jest, i powinna być, szeroko dostępną aktywnością, dzięki której ludzie wspólnie kształtuja świat, w którym żyją ${ }^{50}$. Co więcej, aktywność ta ma sens tylko jeśli ma charakter oddolny, a nie narzucony z góry. Zdaniem Romana Laby, Solidarność odwróciła leninowską zasadę ruchu społecznego. Zamiast „masy”, której świadomość oraz struktura kształtowana jest przez elitę (rewolucyjną awangardę), związek rozwinął się jako ruch oddolny ${ }^{51}$. Jeden z rozdziałów Deklaracji Programowej Solidarności nosił tytuł „Samorządna Rzeczpospolita” i zapowiadał już na samym wstępie, że związek będzie „dążyć zarówno do przebudowy struktury państwa, jak i do tworzenia i wspierania niezależnych i samorządnych instytucji we wszystkich sferach życia społecznego" 52 .

\footnotetext{
${ }^{45}$ V. Havel, Siła bezsilnych, s. 81. Podkreślenie oryginalne.

46 Arystoteles, Polityka, 1275a.

${ }^{47}$ Cyceron, O państwie, s. 54.

48 J. Kuroń, Notatki..., s. 59.

${ }^{49}$ Ibidem, s. 59-60.

50 Zob. D. Ost, Solidarity..., s. 4.

${ }^{51}$ R. Laba, The Roots of Solidarity, Princeton 1991, s. 155.

52 Statut, Uchwała Programowa zaneksem, dokumenty I Zjazdu Solidarności.
} 
Sama struktura oraz praktyka działania Solidarności były najlepszym przykładem przywiązania związkowców do zasady samorządności. To właśnie forma organizacji, jaką był początkowo Międzyzakładowy Komitet Strajkowy, a następnie „sieciowa” struktura związku stanowiły jedno z największych praktycznych osiagnięć Solidarności. Stanowiła ona podstawę wszelkiego demokratycznego działania, zapewniała samorządność i koordynację działań jednocześnie.

Zdaniem Laby, Lech Wałęsa i zdecydowana większość robotników optowała właśnie za taką „konfederacyjną” struktura - w przeciwieństwie do pomysłów inteligencji skupionej wokół KOR, która sugerowała raczej centralizację ruchu ${ }^{53}$. W jednym z numerów „Tygodnika Solidarność” można było przeczytać między innymi, że „podstawą życia związkowego jest samorządna organizacja zakładowa a wyższe szczeble organizacji związkowej maja reprezentować interesy organizacji zakładowych i podejmować demokratyczne decyzje w stałym porozumieniu ze związkowcami poszczególnych zakładów pracy” ${ }^{54}$. By móc sprawnie zarządzać 9 milionami członków, stworzono 10 tysięcy etatowych stanowisk związkowych. Przyjęto przy tym jednak taki system rozliczeń, że składki nie tylko były zbierane lokalnie, ale też pozostawały pod lokalnym nadzorem - tak aby etatowi pracownicy związku czuli się związani z lokalnymi organizacjami ${ }^{5}$.

Przywiazzanie Solidarności do zasady samorządu nie ograniczało się zatem jedynie do słownych deklaracji. Swój najpełniejszy wyraz znajdowało w strukturze organizacyjnej, ale też (a być może przede wszystkim) w sposobie funkcjonowania związku, który był bardzo bliski współczesnym teoriom demokracji partycypacyjnej. Jeden z obserwatorów zaproszonych na I Krajowy Zjazd Delegatów tłumaczył w „Tygodniku Solidarność”, że „miarą demokracji systemu państwowego i jakiegokolwiek mniejszego systemu jest zawsze to, jak dalece demokratyczny jest poziom najniższy (...); na wszystkich szczeblach, wszędzie gdzie zapadają decyzje należy maksymalnie dbać nie tylko o przestrzeganie demokratycznych reguł, ale właśnie o zachowanie autentyczności, spontaniczności działań, jaka towarzyszyła powstaniu związku. Dlatego w gruncie rzeczy ważniejsze od sprawności działania Zwiazku (...) jest zapewnienie możliwie maksymalnego działania zasady demokracji bezpośredniej"56.

W powyższych słowach uderza stopień przywiązania do zasady demokracji partycypacyjnej, która to okazuje się wartością nadrzędną nawet wobec skuteczności działania. To właśnie tego rodzaju poglądy stawały się podstawa do ocen - formułowanych zwłaszcza przez część zachodnich obserwatorów - określających sieciową organizację Solidarności jako zbyt radykalną, a nawet utopijna ${ }^{57}$.

Niezależnie od tego Związek trzymał się przyjętej na początku struktury oraz modelu radykalnej partycypacji. W czasie I Krajowego Zjazdu Delegatów super demokratyczna procedura zezwalała każdemu delegatowi na włączenie się do dyskusji niemalże w każdym momencie. Klasycznie republikański egalitaryzm był cechą przyjmowana w związku za coś oczywistego. Jak zauważył Gawin: „Żywioł publicznej mowy, którego moc została rozbudzona w Sierpniu, obalał wszelkie podziały społeczne i czynił je bezprzedmiotowymi. Język Solidarności znosił podziały społeczne, wszelkie hierarchie i różnice. $Z$ istoty swojej pozbawiony był elementu symbolicznej przemocy - nie dzielił, nie hierarchizował, nie wykluczał, lecz łączył. Zniesienie naturalnej hierarchii i nierówności odbierane było przez uczestników jako kolejny wymiar cudu. Stąd właśnie brało się zadziwienie Kapuścińskiego, że »robole« okazali się ludźmi walczącymi o godność dla wszystkich, także dla nich, stąd też wynikało oszołomienie tą nowonarodzoną »republiką równych«, w której profesorowie siedzieli obok stoczniowców i rozmawiali z nimi jak równi z równymi”"58.

Obserwację Gawina zdaje się potwierdzać Kowalski, który pisze, iż do kanonu solidarnościowego myślenia należało przekonanie, iż „każdy członek wspólnoty ma kompetencje niezbędne do rozpoznania czym jest

\footnotetext{
${ }^{53}$ R. Laba, The Roots...., s. 106 i n. Ash również twierdzi, że struktura sieciowa związku rozwinęła się spontanicznie i nie była „inicjatywą z góry” - zob. T.G. Ash, op. cit., s. 121-122.

${ }^{54}$ Cyt. za: S. Kowalski, Solidarność..., s. 145.

55 Zob. L. Goodwyn, Jak..., s. 463.

${ }^{56}$ Cyt. za: S. Kowalski, Solidarność..., s. 146.

57 Zob. L. Goodwyn, Jak..., s. 551.

${ }^{58}$ D. Gawin, „Solidarość'..., s. 174.
} 
dobro zbiorowe”. To z kolei ściśle wiązało się deliberacyjną forma działania związku - jako jego cechą charakterystyczna ${ }^{59}$. Musimy pamiętać, że na samym początku Solidarność była ruchem opartym na „słowie mówionym" - wypowiadanym na tysiącach strajków, mityngów i zebrań, gdzie robotnicy zbierali się, debatowali, a następnie głosowali. Fundamentalną rolę odgrywały w tym czasie przenośne magnetofony, za pomocą których rejestrowano i przekazywano dalej zapis rozmów. Przemówienia wiecowe krążyły więc pomiędzy zakładami pracy i miastami. Jak zauważa Gawin: „Żywiołem tego, co polityczne, jest język, mowa, demokratyczna debata. Wszystkim autorom piszącym o Sierpniu i Solidarności rzucało się w oczy niebywałe »rozgadanie« tamtego czasu. Nieokiełznany żywioł powszechnej debaty, ogólnego i bezustannego mówienia rozlał się z Wybrzeża na cały kraj. Na tysiącach zebrań organizacji zakładowych związku ludzie nareszcie mogli powiedzieć to, co myśleli i czuli" ${ }^{60}$.

Owa partycypacyjna forma demokracji opartej na deliberacji tkwi jednak swymi korzeniami w teorii republikańskiej (i to w jej klasycznym, antycznym, wydaniu). To właśnie powszechność politycznej partycypacji oraz równość praw politycznych była cechą uderzająca starożytnych poleis. Podobnie jak oparcie życia politycznego na mowie i dyskusji. Śpiewak przypomina, że Ateńczycy obok isonomii (równości praw politycznych) i isokratii (równości władzy) rozpoznawali też isegorie - równe prawo przemawiania na zgromadzeniach politycznych ${ }^{61}$.

Wspomniane przez Kowalskiego przekonanie panujące wśród członków Solidarności - zgodnie z którym każdy członek wspólnoty posiada pewne minimum kompetencji niezbędne do decydowania w sprawach dotyczących dobra wspólnego - odnajdziemy w najwierniejszej postaci właśnie u starożytnych Greków. To przekonanie - zastosowane w praktyce - sprawiło, że „w ciągu piętnastu miesięcy wytężonego wysiłku i zaciętych sporów wewnętrznych, rozmaite warstwy polskiego społeczeństwa stawały się kolejno wiernymi członkami ateńskiego polis, pełnymi cnót obywatelami Renesansu, budowniczymi ustroju republikańskiego (...) i, na koniec, bojownikami o autonomię swej republiki"62.

W powyższym opisie nie brak oczywiście pewnej idealizacji. Można się jednak poważnie zastanawiać, czy nie wynika ona z obecnej w ideologii i praktyce Solidarności utopijności. Utopijność taka charakteryzowała zresztą w jakimś stopniu antyczne poleis, które za powszechność charakteryzującej je partycypacji oraz procedury bezpośredniego uczestnictwa płaciły cenę w postaci niestabilności politycznej.

Solidarność pojawiła się jednak w wyjątkowym momencie - w sytuacji, w której stopień ubezwłasnowolnienia obywateli przez partię rządząca był tak wysoki, że doprowadził do powstania autentycznego poczucia wspólnoty oraz umożliwił przełamanie barier klasowych. Całkowite zawłaszczenie sfery polityki przez aparat partyjny, umożliwiło wykształcenie się jej utopijnej formy - silnie zabarwionej etycznie. „Tam, gdzie nie było czystej »polityki«, tłumaczy Gawin, „, w większą łatwością sięgano do poziomu czystej polityczności; tam gdzie jeszcze nie istniała ani "prawica« ani »lewica«, łatwiej było budować wspólnotę polityczną na fundamencie jedności; tam gdzie nie pojawiła się jeszcze ideologia, z większa łatwością posługiwano się językiem pierwotnego republikanizmu. Tam wreszcie, gdzie nie powstały jeszcze "partie«, mające na względzie przede wszystkim interes »części«, łatwiej było rozpocząć od budowania »solidarności« nakierowanej na »całość«"63.

Po roku 1989 szybko okazało się zresztą, że ten idealny model republikańskiej wspólnoty zorientowanej na dobro wspólne, nie wytrzymuje konfrontacji z nowoczesna pluralistyczną, a zarazem silnie ideologiczną polityka, charakterystyczną dla czasów masowej demokracji liberalnej ${ }^{64}$.

\footnotetext{
${ }^{59}$ S. Kowalski, Solidarność..., s. 165.

${ }^{60}$ D. Gawin, „Solidarość”..., s. 171.

${ }^{61}$ P. Śpiewak, Obietnice..., s. 35. Na temat powszechności politycznej partycypacji w Atenach - zob. D. Gawin, Ateny i Rzym.

Dwa źródła zachodniej polityczności, „Res Publica Nowa” 1998, nr 9 (120), s. 33.

${ }^{62}$ L. Goodwyn, Jak..., s. 409.

${ }^{63}$ D. Gawin, „Solidarnośc’..., s. 175.

${ }^{64}$ Innym przykładem tej samej prawidłowości mogą być Stany Zjednoczone Ameryki, w których to pierwsze partie polityczne (Federaliści i Republikanie) w zinstytucjonalizowanej formie pojawiły się zaledwie parę lat po powstaniu Unii - dokładnie w tym samym czasie, w którym przywoływany wcześniej Jerzy Waszyngton apelował do swych współobywateli o unikanie podziałów partyjnych.
} 


\section{Zakończenie}

Powszechne w literaturze przedmiotu kojarzenie ruchów dysydenckich oraz rozwijanych przez opozycjonistów idei społeczeństwa obywatelskiego z myślą Gramsciego jest, rzecz jasna, w dużym stopniu uzasadnione. Znaczna część opozycjonistów, pozostająca w kręgu myślenia lewicowego i neo-marksistowskiego, w sposób naturalny odwoływała się do idei i autorów najlepiej im znanych. Analiza ich treści pokazuje jednak, że być może trafniejszym tropem byłoby analizowanie koncepcji ,anty-politycznej polityki” Havla, czy praktyki polskiej Solidarności przez pryzmat pism Arystotelesa, Cycerona, czy Polibiusza. Robotniczy charakter związku zawodowego, jakim była Solidarność w sposób niejako naturalny kieruje nas w stronę socjalistycznych i anarchistycznych koncepcji rad robotniczych. Okazuje się jednak, że polscy robotnicy w dużo większym stopniu - choć zapewne zupełnie nieświadomie - wcielali w życie klasycznie republikańskie koncepcje polityki zorientowanej wokół kategorii samorządu, dobra wspólnego, czy solidarnej wspólnoty politycznej; wspólnoty o charakterze etycznym i - do pewnego stopnia - organicznym (nie zaś formalno-prawnym).

Punktów zbieżnych jest zresztą więcej: powtarzające się postulaty dotyczące wolności, czy autentycznego przestrzegania zasady rządów prawa - również nie są przecież wynalazkami wspomnianych przez Havla „teoretyków socjalizmu”. Są to idee o wiele starsze, rozwijane i praktykowane już w starożytności, a fakt ich dość spontanicznego i nie zawsze uświadomionego - przejęcia przez Solidarność świadczy jedynie o ich ponadczasowości. Z pewnością ich dosłowne zastosowanie - w formie zbliżonej do klasycznej, „czystej” postaci - byłoby dziś niezwykle trudne, może wręcz niemożliwe. Okres piętnastu miesięcy rozpoczęty w sierpniu 1980 roku w Polsce był wszelako okresem wyjątkowym. Być może jednak to właśnie w wyjątkowych czasach i wyjątkowych okolicznościach owo klasyczne, republikańskie rozumienie polityki ma największe szanse zaistnieć i ujawnić się w całej swej unikalności.

\section{Bibliografia}

Arystoteles, Polityka, Warszawa 2004

H. Arendt, Kondycja ludzka, Warszawa 2000

T.G. Ash, Polska Rewolucja. Solidarność, Londyn 1987

Civil Society and the State, ed. J. Keane, London 1988

Cyceron, O państwie. O prawach, Kęty 1999

Eseje polityczne federalistón, red. F. Quinn, Kraków 1999

D. Gawin, Ateny i Razym. Dwa źródta zachodniej polityczności, „Res Publica Nowa” 1998, nr 9 (120)

P. Gliński, The Self-governing Republic in the Third Republic, „Polish Sociological Review” 2006, nr 1 (153)

L. Goodwyn, Jak to zrobiliscie? Powstanie Solidarności w Polsce, Gdańsk 1992

V. Havel, Siła bezsilnych i inne eseje, oprac. A. Jagodziński, Warszawa 2011

V. Havel, Eseje polityczne, Warszawa 1984

S. Kowalski, Solidarnośćcolska. Studium z, socjologii myślenia potocznego, Warszawa 1988

J. Kuroń, Polityka i odpowiedżialność, Lublin 1986

R. Laba, The Roots of Solidarity, Princeton 1991

Lekcja Sierpnia. Dziedzictwo „Solidarności” po dwudziestu latach, red. D. Gawin, Warszawa 2002

A. Michnik, Szanse polskiej demokracii, Londyn 1984

Monteskiusz, O duchu praw, Kraków 2003

D. Ost, Solidarity and the Politics of Anti-Politics. Opposition and Reform in Poland since 1968, Philadelphia 1990

Statut, Uchwała Programowa z aneksem, dokumenty I Zjazdu Solidarności (teza 19), http://www.wszechnica.solidarnosc.org.pl/?page_id=612 (dostęp: 6 kwietnia 2016 r.)

J. Szacki, Liberalizm po komunizmie, Kraków 1994

P. Śpiewak, Obietnice demokracji, Warszawa 2004 
Uchwała programowa I Krajowego Zjazdu Delegatów Niezależnego Samorzqdnego Zwiazku Zawodowego „Solidarnośc”, http://www.wszechnica.solidarnosc.org.pl/?page_id=1370 (dostęp: 6 kwietnia 2016 r.)

Wiara i wolność. Doświadczenie i dz̧iedzictwo pierwszej „Solidarności”, red. ks. A. Kobyliński, Płock 2001

Wiæje Stanów Zjednoczonych w pismach Ojców Założycieli, oprac. W. Osiatyński, Warszawa 1977 